\title{
The Entanglement of Nation and Epistemology: Glances into the Backyard of Academic Dignity
}

\author{
Stephanie Fox \\ University of Vienna
}

\section{Abstract}

This article addresses the phenomenon of 'national epistemologies' that are understood as particular ways to think about the world, both enabled and restricted by national(ist) ideologies as cultural thesis about distinct commonality and togetherness. With regard to methodology, the article describes on a general level how these 'national epistemologies' can be identified and particularly how their development as nationally idiosyncratic ways of conceptualizing and conducting research can be explained, taking the academic field of education as an example. The existence of such distinct national research thought styles can be detected, at least in the West: in the United States, in France, in England and in Germany. Thereby, imperial aspirations of these nationally connoted and configured phenomena come to the fore, indicating their efforts of spreading from epistemologically stronger nation(-state)s into weaker ones in the way of 'travelling ideas'. Starting from the thought style represented by German Idealism, two major reasons or purposes for these travels can be distinguished: One 'by invitation' and one 'as occupation', as represented by the case of Austria.

Key words: Austria; education research; national epistemologies; nationalism; travelling ideas.

\section{Introduction}

Doing education research often means practicing a certain way of research that includes methods, research questions and foci which have been important in individuals' academic careers. More precisely, researchers apply what they themselves have learned to consider as important, as worthy of being researched and as an appropriate method. These practices culminate in a whole complex of 
theories, methods and results that are supposed to be 'true', that is, in a particular epistemology. Yes, as this paper argues first, there is not one single way of (doing) education research, or only one epistemology which is valid and applied all over the world, but several. Furthermore, it will be argued that these particular epistemologies are, as a rule, nationally connoted, expressing a unique and idiosyncratic perspective on and of the world and, therefore, also of academia in general and of education research in particular. Surprisingly, whereas nationalism has become an established field of research at least since the 1960s in history, geography, anthropology, economy and sociology (Wimmer \& Glick Schiller, 2002), this has rarely been the case in education research (Tröhler \& Maricic, in review). However, the fabrication of loyal national citizens through education (Tröhler et al., 2011; Harp, 1998) as well as the construction of national identity (Wodak et al., 2009) have absolutely become accepted research topics in education. In contrast, the confrontation with nationalism addressing and affecting not only others but also (the epistemology of) ourselves as researchers is (at least) a delicate issue within the scientific community.

In order to take this phenomenon adequately into account, an attempt has been made in five steps to make this thesis plausible: The first part deepens and explains the assumption of national epistemologies in education research in order to clarify what we are talking about. In the second part, it is shown which methodological assumptions are fundamental to this approach and - coming to methods - how national epistemologies can be discovered and identified as such, and which concrete methods are therefore applied. In order to analyze what happens when there is no unique national epistemology in place, the third part presents analytical categorization tools of travelling ideas together with the two major reasons or purposes of the transnational journey of ideas, 'by invitation' and 'as occupation'. The fourth part refers to the case of Austria as a case of the more interesting purpose of travel in this respect, namely as a place of intellectual invasion by German Idealism. In the fifth and last part of this article, the conclusion and the outlook show what the results mean for education research and what they could offer for further thinking and research.

\section{National Epistemologies - Differences become apparent only in comparison}

The national character or the 'nation-ality' of thought can already be identified in particular terms, but also in conceptual drafts of different national education systems, and even in epistemological writings.

Key-terms, as obvious articulations and expressions of nationalized thinking, show their substantial impossibility of translation and, therefore, their uniqueness and national embeddedness. For example, the American 'citizen', the French 'citoyen' and the German 'Bürger' do not have identical meanings or implications, nor do 'education' in English, 'éducation' in French and 'Bildung' in German (Tröhler, 
2018). The reasons for these non-matchings are core differences within the cultural ideologies that are silently expressed by the terms which have imbibed particular ideological, that is as a rule national, shapes during the long 19th century. Thereby, each national shape can be understood as an amalgam of different emphases or weighings of political, cultural and religious preferences. Hence, these conceptual examples testify to a 'linguistically expressed nationalisation of thought patterns' (Tröhler, 2018, p. 176; own translation) for it is the national strength within/of the nation-state, the intensity of both the nation as 'imagined community' (Anderson, 1991) and its national(ised) thinking, that is being expressed in, in the end, an epistemological persuasion.

Hence, conceptual drafts for the education systems in different nations are not only written in the different spoken languages but more particularly also in different ideological languages, each of them expressing unique national idea(l)s, ideologies, ambitions and idiosyncrasies. This can be evidenced, for example, by five designs of three different national spaces, all of which were created during the early nationbuilding period around 1800. The German educational philosopher Wilhelm von Humboldt wrote two prominent school plans, the Königsberger Schulplan [Koenigsberg school plan] and the Litauischer Schulplan [Lithuanian school plan], in 1809 aiming at general human education/development [allgemeine Menschenbildung] taking place in the inner soul of the human being through a tiered education system with grammar or secondary schools [Gymnasien] as gatekeepers of the universities whose focus was on ancient languages such as Latin and Greek (Humboldt, 1809/1920a; 1809/1920b). Similarly meaningful but conceptually fundamentally different are the two American drafts by Noah Webster (1790), named On the Education of Youth in America and, a bit earlier, in 1786, by Benjamin Rush, On Education (1947). Both of them highlight the importance of equality and liberty through virtues realised in a republic of free and self-governed citizens as well as the relation of (Reformed Protestant) religion, politics and education. Being concerned about the social, and, in this sense, outer life is exactly contrary to the German model which aims at inwardness. The French draft of the Marquis de Condorcet, Rapport et projet de décret sur l'organisation générale de l'instruction publique [Report and draft decree on the general organisation of public education] from 1792 is much more similar to the American design than to the German one, since here, too, a republic is assumed as the political organisation system. Condorcet, thus, in his elaboration, focusses on social participation and progress, general wealth and a consecutive school system which is self-monitoring through science and elected representatives, established (but not controlled) by the state with an emphasis on rational reason.

All of these ideal conceptions are borne by and express national-cultural patterns which are deeply rooted within the different cultural theses of nationality or nationstates and their citizens, and stately organised into a whole apparatus that makes up 'national literacies' as described by Tröhler (2020). 
These national-cultural patterns do not remain suspended with private citizens, they do not stop at scientists - as we all breathe the same (nationalised) 'airs' - but they continue in epistemologies in academia or are expressed and reflected by them. This becomes obvious already by looking at the (names of the) arguably most famous epistemologies or epistemological philosophies such as (for the West, at least) English Utilitarianism and Empiricism; German Idealism - in the latter the abovementioned notion of inwardness is crucial -; American Pragmatism - in which the reasonable, virtuous cooperation in the social 'outer' world is fundamental again; and French Positivism and Rationalism - where, in the latter, the ratio again appears as a central element. Here, in all of these national epistemologies, nationalised thought patterns, ideals of and aspired identifications between the individual, the nation and the state in the network of relations between nationalism and education find their manifestation; and even the national identification in each case is no coincidence but an expression of the equivalence between nation and epistemology.

\section{Methodological approaches and methods}

In the following it will be shown which methodological assumptions are fundamental to the thesis of national epistemologies and how they can be method(olog)ically uncovered and identified. Methodologically-speaking, three elements are necessary: a sociology of knowledge, a linguistic-ideology, and a theory of (institutionalised) power.

The first element represents a crucial sociological approach with regard to academic knowledge production. The work of the Polish physician and biologist, Ludwik Fleck, neglected for decades, has once again been strongly adopted (Radeiski, 2017). Fleck observed that each perception of something as this particular something is developed in a specific intellectual-social context. Researchers, and as such also human beings in general, within the same context share a way of perceiving according to their shared conditions and understandings. They develop a mutual 'thought style' which is constituted by their particular 'thought collective' (Fleck, 1999), and vice versa. Since the configuration of a particular way of thinking, a unique thought style, indicates not only favoured (research) perspectives and questions, methods and goals, but also preferred values, aspirations and ideologies, it is reasonable to go one step further with the notion of national thought styles which have become materialised in explicit terms. In academia, national thought styles are borne - in the same way - by nationally deployed thought collectives and 'fabricate' corresponding ways of producing knowledge: national epistemologies as national thought styles are borne by their nationally organised thought collectives, as for instance in education research within AERA, AECSE, BERA and DGfE with their respective sub-divisions and their members, professors and students. Hence, as already indicated, we do not talk randomly about Pragmatism in general but about American Pragmatism, just as we talk about French Rationalism and Positivism, English Utilitarianism or German 
Idealism. Fleck's conceptualisation matches very well with the linguistic approach described next because academics (amongst others) also think within 'communities of language' (Fleck, 1999), thus indicating Fleck's thought collectives which use the same linguistic (thought and uttering) conditions.

The constitutional cultural conditions of the key terms of utterances refer to the second element, the linguistic approach in which language is understood in or turned towards its ideological dimension(s) (see also the article by Veronika Maricic in this issue). Since the 1960s, the cultural and historical sciences have been affected by the linguistic turn (Tröhler \& Horlacher, 2019; Tröhler \& Fox, 2019), which basically describes a research preference highlighting the linguistic constitution of reality. With this approach, an epistemology is understood as a linguistic configuration of a particular thought style. In this way, a thought style can be 'read' as a 'language' the way it is, in education, first explained in Daniel Tröhler's 'Languages of Education' (2011). He follows the New Zealand historian of ideas, John G. A. Pocock (1987), who, in turn, refers to the crucial differentiations made by the Swiss linguist, de Saussure (1916/2016). These differentiations are, namely, between langue as a culturally emerged system (of meaning) and parole as the concrete uttered speech act (de Saussure, 1916/2016, pp. 16-17). For discourse analysis, the particular paroles need to be understood from the langue from which they arise, as utterances of a unique thought style, for it is the langue that shapes the particular meaning of the respective parole. Pocock's analytical focus lay on political languages, whereas Tröhler explored educational languages (or: 'systems of reasoning' according to Hacking (2002)). Both Pocock and Tröhler emphasise the ideological character of these languages. Here, the linguistic based approach is central for the necessary analysis of thought styles since 'texts [should] be treated as products of specific historical contexts, ... ideological contexts formed through linguistic practice' (Whatmore, 2017, p. 42; own emphasis).

The third methodological aspect refers to the French philosopher, Michel Foucault's, thoughts concerning ubiquitous operating power relations (Foucault, 1976). Following Foucault (1969/1973), structures of thought are always results of power and reality as it appears is a constructed discursive product. Escalating Foucault's words, the institutional solidification of strategic power relations is also embodied in academic (education) institutions, where, consistently, the respective 'realities' manifested in according epistemologies have been produced. A look at the 'discursive formation' (Foucault, 1969/1973, p. 185) displays that power structures help the decidedly national ways of reasoning look 'natural', and hence seemingly without alternative. The understanding of nationalism as an institutionalised (Özkırıml, 2010, p. 208), power-connected discourse borne by the concept of thought collectives (Fleck, 1999) reveals the national academic 'game': Academic thought collectives are the intellectual 'locations' of knowledge-production and they are evidently organised in national research associations like the ones mentioned above, but also, of course, 
in and across institutions of higher education. Among them, universities convene a considerable amount of power. For it is not without reason that Surman (2019) describes them as centres for both state- and nation-building, or, as Koch (2008) wrote (concerning Prussia after the territorial reorganisation of Napoleon), as aids to "strengthen again the self-confidence of the state, which as a "cultural state" (Kulturstaat) would try to make up for what it had lost as a military power' (p. 134; own translation). Universities are broadly self-regulated in determining research and teaching (curricula), in promoting their junior staff and making their own decisions about new appointments, thereby highlighting not only potential power mechanisms but also the capability of perpetuating one way of reasoning (Özkırıml, 2010, pp. 27-28). Thus, institutionalisation, with its inherent power mechanisms, is a fundamental and determining force both for discourses in enhancing and for thought collectives in securing and passing on their knowledge. In this way, one particular thought style becomes capable of gathering power up to hegemony and dominance. Finally, nationalised thought within educational epistemologies seen together with Foucault's analysis as social practice - which reproduces power relations and naturalises them - can be found in the manifest discourses and identified through the concrete paroles. These paroles, at the same time, show the unsaid and excluded by looking at what is actually expressed how and what is not.

Against the background of these methodological considerations, concrete methods are then also necessary as applicable working tools and steps. Source materials for researching the 'nation-ality' of thought styles are comprised of primary texts from the respective key figures of national educational thought, such as William James and John Dewey for the United States or Eduard Spranger and Herman Nohl for Germany. Surveys, nation(al) -, social -, appointment -, and university histories, lecture catalogues and other archival material help to reconstruct the multilayered development of the (institutionalised) sociological levels of knowledge. In this regard, the methodical steps range from archive and network research to literature analysis and linguistic-ideological discourse analysis. The time period under study, in turn, ranges from the late eighteenth century to the present day, depending on the nation(al epistemology) concerned.

\section{Travelling ideas in education research}

So far, what can be understood by 'national epistemologies', how they arise and how they can be identified has been described. Notwithstanding that the different ways of reasoning are nationally distinctive and nationally distinguishable, it is remarkable that not every nation(-state) has developed a unique epistemology in its education research. According to the comparatist William K. Cummings (1999), the only model-like patterns which have been developed in the modern era have been those in the United States, in the United Kingdom, in France, in Prussia/ Germany, in Japan and in the Soviet Union/Russia. This was because these were the 
only societies that both enjoyed continuing national integrity and were sufficiently powerful as to have extensive influence ... over other nations. Education in most other modern settings came to emulate the education institutions [understood also as epistemologies] of these six core nations' (p. 428) - even if they have been adjusted or modified. Following Cummings - however, here restricted to the Western World -, there is, obviously, a difference between the nations with regard to their epistemological power in knowledge-production. It must also be mentioned that the transnational flows or travels of ideas within science in general is not a new phenomenon but rather a well-tried good which is related to (epistemological) power (whereby 'idea' serves as a floating signifier for a range of possibilities from single theories up to whole complexes such as epistemologies). Two major purposes or reasons serving as explanations for when an epistemology has been identified as 'out of place', a foreign place different from the place of origin of the national epistemology, will be put forward. These purposes or reasons, just as the 'strong' and 'weaker' nation(-state)s, have to be seen as (the ends of) a range, and not as static points of assignment of either/or. Nevertheless, the reasons for the travelling of these are not at all incidental, but rather the opposite; they are, namely, fundamental for understanding the prevailing epistemological situation in a particular space.

The two major reasons or purposes of travel can be called travelling 'by invitation' and 'as occupation'. Both of these purposes convene a substantial amount of power, yet in ways that differ from each other in holding power and exerting power. They are explained as follows.

The first reason, 'travelling by invitation', is more likely to happen in (epistemologically) strong nation(-state)s that have developed unique national educational ideas into which the invited travelled idea becomes integrated in various ways. The first of these ways can be called epistemological implantation and indicates situations when foreign ideas become discussed in or even implemented into a 'unique' national thought style while staying (more or less) contextualised as foreign thought - a common practice in international research. The second way can be labelled as an epistemological appropriation and describes situations where it became more and more obsolete to contextualise the foreign travelled ideas within their national roots of origin. A famous example of such an approach is the rise and success of French poststructuralism and deconstruction associated with French philosophers like Foucault, Derrida and Deleuze, especially in North America (Whatmore, 2017, p. 33). The original ideas become indigenous in a new national context by imitating the 'mental climate' (p. 33) of the original thinkers.

In education, Denmark is then an illustrative case that represents an epistemological implantation, namely of German Idealism, especially in terms of its core subject matter and the notion of Bildung, as Buchardt (2020) describes with regard to modernising processes following the Cold War in the nineteenth century Nordic education reforms. The German idea(l) of Bildung as inner improvement of the soul 
was not simply taken over and continued as 'Bildungs-concept' but was implanted into an existing concept of its own, in this case, into the Danish national notion of dannelse. Whereas dannelse still draws more or less explicitly on the German notion of Bildung, meaning that it remains contextualised within German origins, it has been, at the same time, recontextualised within the Danish context and for its actual need for doing this epistemological implantation, which was, by that time, nation-state crafting and modernisation (Buchardt, 2020; Buchardt et al., 2012). Furthermore, when it comes to Danish educational research, the link to German Idealism is more than obvious, as can be read in Nordenbo (1997, p. 212) - not only is Bildung itself discussed but also prominent German Idealists, such as Hegel, and their forerunner and source of ideas, Kant. This example shows very clearly how foreign-national ideas have travelled by invitation, remain contextualised and are fitted into one's own education system - in order to serve a particular need of the 'host location'.

The second purpose of travelling ideas, 'travelling as occupation' or even 'epistemological colonialization', can be described as an exportation of a national epistemology to a foreign destination where it starts to spread. This case is more likely to happen in (epistemologically) weak(er) nation(-state)s. Some five possible ways of intellectual occupations can be detected. First, unintentional 'occupation by invitation' can occur in the wake of the establishment of universities with hardly any domestic scholars to be hired, as in the cases, for instance, of the University of Bahrain in 1986 or in Luxembourg after 2003. A second type goes along with the political, military and economic colonialization of the traditional colonies, for instance in Africa. A further type is illustrated by the re-education programme of the inhabitants of Western Germany after the Second World War, representing an attempt at replacing an existing epistemology backed-up by military power. A fourth case is the epistemological occupation of the former GDR after 1989 in the context of its reunification with Western Germany. Still another case can be observed which involves no military or political power, namely in the global dissemination of testpsychology in programmes like TIMMS or PISA.

\section{Austria as a case of intellectual occupation by German Idealism}

A closer (and above all epistemologically-interested) look at Austria shows how worthwhile it is to examine the 'small(er)' or 'weak(er)' nations, or, at least, partial nation-states, in education research (as has been done in this issue, for example, by Rebekka Horlacher and by Michèle Hofmann for Switzerland, by Felicitas Acosta for Argentina and by Marva Shalev Marom for Israel). As for Austria, it is worthwhile to look not only at the time when it became an independent nation-state after the breakdown of the Habsburg Monarchy in 1918, but at the time when education was institutionalised at the university. This happened in Austria, or rather in Vienna, as the constant intellectual, cultural and political center of Austria, from the turn 
of the nineteenth century onwards; or, more precisely, in 1806 with the end of the Holy Roman Empire of the German Nation.

It is interesting that the relation between Austria and its neighbour 'Germany' has always been 'close' and intense over the last centuries (see Nicole Gotling's article in this issue), in good and in bad times - either in companionship and connection or in rivalry and delimitation. After the First World War, during the interwar period and again after the end of the annexation of Austria to the German Reich, it was evident that Austria, as compared to Germany, was in many respects a 'weak(er)' nation-state. This was not only because Austria was a more belated nation-state than Germany, whose establishment (as a nation-state) was in 1871, but also because, for example, some scholars have even argued that today's 'Austria' could fully burgeon or develop its national identity and conscience only after the Second World War when it became the Second Republic (see Beller, 2017; Boyer, 1989; de Cillia, 1995; Haderlap, 2018), which is not even 80 years ago. Remembering that Ernest Renan (1882/1992, p. 10.) was describing a nation as 'a soul' already in 1882, for Austria's twentieth century, a 'national soul searching' (Weiss, 2000, p. 89) was described. Even though there have been a small number of studies focusing on German-Austrian relations in the twentieth century, these have neither paid much attention to questions of sociocultural interaction nor to questions of epistemological 'exchange' (Vermeiren, 2011, p. 200). Still, apparently 'Austria [was] failing to create a new "Austrian" identity' (Beller, 2017, p. 197) right at the beginning of its enforced 'birth' as a nation-state after the First World War.

As Cowen (2009) suggested, a crisis like the end of an empire or wars affect not only domestic knowledge-production but also cross-border, i.e. transnational, flows of ideas. As for Austria, both of these definitively hold true and can be supported by literature and curriculum research of the University of Vienna. As for the domestic knowledge production, it can be said that, in Austria at the turn of the twentieth century, there have been strong attempts towards a potential 'Austrian thought style' which, however, have been badly compromised by the Nazi Regime and concomitant emigration from Vienna. Interestingly, the last three 'Austrians' winning an academic Nobel prize were all Austrian born Jews who had to leave Austria in the 1930s and who then worked in the United States, their awards listing them as US-American. All of them had to leave Austria when they were young and they referred to a strong academic tradition in the realm of the University of Vienna with many Nobel prize winners in the nineteenth century. In the field of cultural sciences, there was a comparable brain-drain of indeed unique epistemological styles, borne mostly by Jewish-born Austrians, firstly of the psychoanalytical theories in the early twentieth century and the escape from Vienna not only of Sigmund Freud himself in 1938 (to London) or Alfred Adler in 1934 (to the United States), and secondly of the popular Viennese Circle (Wiener Kreis), which had been informally organised since 1907, and whose members became partly deported by Austro- 
Fascism and National Socialism or murdered as in the case of Moritz Schlick in 1936. This brain-drain caused an epistemological vacuum and the obvious idea of annexation to Germany implied the more or less unhindered epistemological flow of German Idealism into Austria. This leads to the second 'effect' mentioned by Cowen, namely, the transnational flows of ideas which were, in the case of Austria, highly increased as far as they concerned the intake of ideas. Actually, in each of the times of crisis - both in times as an empire ended, 1806 and 1918, and again after the Second World War -, German national educational thought came into Austrian university education, as can be seen in the lecture catalogues from the University of Vienna archive and well-elaborated in Wolfgang Brezinka's (2000) work about education in Austria.

Not only for Austria, it is also especially interesting to look at the time when education was institutionalised at the university. The first time education appeared as a separate discipline at the University of Vienna was in 1806. The Roman Catholic Prince-Archbishop of Vienna, Vincent Eduard Milde, was assigned to teach Erziehungskunde (education) for which he wrote a particular Lehrbuch (textbook) in 1814, which was taught until the middle of the century. A content and linguisticideological discourse analysis shows that Milde, who was actually more interested in the vocation of priests and in oriental languages, had adopted core ideas in his textbook - in terms of content, thought/argumentation and design - from a textbook originally written in 1799 by August Hermann Niemeyer, a German Protestant and great-grandson of the pietistic August Hermann Franke; however, credit to Niemeyer is not to be found in the textbook. In any case, both Milde and his ghostwriter, or at least muse of ideas, Niemeyer shared the silent combination of two elements. The first element is the moral philosophy of the German PietistProtestant philosopher, Immanuel Kant, regarding his orientation towards reason and its limits as well as his view of man, who is subject to the eternal, ultimately religious, natural laws. Man is supposed to understand these laws, but in the end, they can ultimately only be justified by faith. This relation to faith and religion reappears in the pietistic inspired motifs in both of the textbooks, namely in the motifs of inwardness, introspection and self-examination. Milde (1821, p. 14), in this regard, wrote about the importance of remembering and thinking about oneself, one's past, (felt) experiences through self-examination (p. 6), just as Niemeyer (1818, pp. 6-7) had written about the depth of experiencing one's own inner life. Another identical element refers to some of the classical convictions of German Idealism, such as the strong dualism of the inner and outer worlds in which the mind/soul/Geist (spirit, mind), natural abilities, senses and Bildung (inward notion of education) belong to the inner world, while the body, the world (in a material sense, that is nature), influence/ impact (Einwirkung; what is done by the educator) and Erziehung (outward notion of education) are counted as strictly separate and of the outer world. In both of the books, such similar elaborations about the körperliche Anlagen (physical faculties) and the geistige Anlagen (mental faculties) can be found, along with explanations on how 
to treat and teach them appropriately (Niemeyer, 1818, p. 3; Milde, 1821, pp. 1-2). A further shared idealistic element is the perspective of human beings as individuals (and not, for example, as social beings) (Niemeyer, 1818, p. 13; Milde, 1821, pp. 14$15,85)$. A third conviction is represented by the pursuit of 'perfection' and the ideas of 'perfectibility' and harmony as the ideal of perfect humanity (Niemeyer, 1818, p. 4; Milde, 1821, p. 3). A fourth common idealistic feature is the characteristic of the a-political, in that the state and society confront man as a single, individual person, i.e. he is not part of the state or society since man is an end in himself and has no state purpose (Niemeyer, 1818, p. 5; Milde, 1821, p. 15).

Milde also did not provide his textbook for sale anywhere, but it was sold by an immigrant German Protestant bookseller, Christian Gottfried Kaulfuß. He, Kaulfuß, explicitly advocated that 'masterpieces of German poets and prose writers' (Heydemann, 2000, p. 122; own translation and emphasis) be made available to the Austrian Empire (Heydemann, 2000, p. 122). Thereby, with the Germannational connotation, he meant, territorially, the former Holy Roman Empire of the German Nation, as well as German translations of inventive ideas from abroad. In this respect, Milde was in exactly the right place with his (taken over) GermanProtestant textbook for sale.

This phase, in the first half of the nineteenth century, represents the rather unintentional occupation by invitation of German Protestant Pietist-idealistic thought, but not in people, as mentioned for the case of Luxembourg, for example, but 'only' intellectually, since Milde probably simply did not know what else to look for and therefore turned to his own sources of knowledge. Yet the Austrian connection to Kant, and thus to German Idealism, remained in the second half of the nineteenth century, after Milde's death, with the Saxon Theodor Vogt (Brezinka, 2000, pp. 271). Vogt was the first to write his habilitation in Vienna; and, once in the chair of education (and later philosophy, too) at the University of Vienna, from 1865-1906, he wrote about Greek aesthetics, taught Herbart's ethics, lectured about Kant and emphasised the nationalist Addresses to the German Nation (1808) by Johann Gottlieb Fichte (Universität Wien, 1831-2004), which testifies to an increase in nationalismrelated issues, including in academia, and also nationalised thinking in general.

In Austria, the periods shortly before, during and after the First World War (the interwar period) were characterised by ambivalences, contradictions and the predominance of ambiguity with regard to Austria's nationality - which is even reflected in the range of courses offered in the University of Vienna's lecture catalogues (Universität Wien, 1831-2004). German Idealism was still being taught (by Germans), but parallel to this there were also courses provided by non-Germans (from Germany). These included lectures on pragmatic drafts by the Jewish Bohemian, Wilhelm Jerusalem; hygienic pedagogy from the Viennese, Leo Burgerstein and from the Catholic Austrian Alois Höfler, who was interested in psychology and logic (Brezinka, 2000, pp. 288).

Together with Willibald Kammel and later with Richard Schwarz (the former taught 
from 1919 until the Second World War and again afterwards, the latter taught only after the Second World War) (Brezinka, 2000, pp. 388), the notion of Bildung, the epitome of the German Geisteswissenschaftliche Pädagogik (Humanities education), an offspring of German Idealism, started to spread and become as epistemologically as culturally dominant. The concept of Bildung, together with its German-national epistemology of, in its origins, German Idealism, would come to stay prevalent until today (Universität Wien, 1831-2004). This intellectual and knowledge-sociological history of the Austrian academic history within education testifies to a massive German-intellectual invasion in the wake of travelling ideas just as, at the same time, to the potential of imperial aspirations of such powerful nations (or national epistemologies) such as Germany (or German Idealism).

\section{Conclusion and outlook}

Considering that this thesis assumes dominant ways of thinking and does not deny a potential simultaneity of (sometimes less-strongly) coexisting ways of reasoning in the same place, it has been shown how close the connection between (strong) nation and epistemology is and how imperial the result of these national epistemologies can be, or, as in the case of Austria, is.

This research interest is not completely new, as a group of scholars, foremost Andreas Wimmer, have become popular in explicating what they have labelled 'methodological nationalism' (Chernilo, 2011; Wimmer \& Glick Schiller, 2002), that is the impact nations/nationalisms have on distinctive styles of research; or also Ulrich Beck $(2002 ; 2005)$ is concerned with claiming a shift towards a 'methodological cosmopolitanism' within science. Yet, whereas the former have been claiming to overcome this methodological nationalism, here, recognize epistemological nationalisms is urged, since, as has been described, what we consider as 'reality' or 'truth' is a cultural, social, linguistic and, in the end, national construction of a respective time and place. The nation or nationalism, therefore, can serve 'a desire to regenerate a sense of commitment among fellow nationals' (Rodrik, 2019, p. ix) in a social regard and, as a cultural thesis, as a 'way of speaking that shapes our consciousness' (Calhoun, 1977, p. 3). In contrast to popular global development theories, the different nationalisms are to be understood as making evident that nation and state depend on and 'work' with each other, as appeared in the respective nationalisms in order to strengthen the particular nation-state.

Against this background, and if (research on) nationalism is taken seriously into account in education research, it also means that it must be acknowledged that there are, first of all, different ways or forms of nationalism (also in education). Furthermore, it is noticeable that there are different strengths of nationalism which, as it has been shown here, have materialised into distinguishable epistemologies, either in unique national ones or in travelled (inter-)national ones. Without aiming at reproducing the construction of nations, since unique epistemologies are configured in some kind of strong nations and spread imperially into weak nations' academia, this 
also means that, epistemologically at least, only the strong are really the academic playmakers. Nevertheless, here, the national path dependencies of epistemologies in light of the meaning of cross-national travelling ideas have been explored in order to discover the multilayered systems and complex power mechanisms that are the basis of each respective educational reasoning. Including such research approaches within education research could contribute to the examination of how knowledge production is generally framed by national contexts, and how it is both a constitutive element of nation-building and, at the same time, and maybe paradoxically, characterised by international hegemonic aspirations.

As for further research in this direction, it is interesting to consider the relation between nation and religion or, more precisely, nation and its respective dominant religious denomination(s). As Tröhler (2017) argues, it is both nation and religion that frame the different ways of reasoning, and so it is all the more remarkable that all of those nation(-state)s that indeed have developed a unique national epistemology are not mainly Catholic but more of any Protestant denomination; thus, being (epistemologically) strong could go hand-in-hand with being non-Catholic and, the other way around, being (epistemologically) weak could be associated with Catholicism. Such a thought could make sense, at least if one considers that Catholics already have a reference institution in which their faith is lived and in which the soul can attain salvation: the Church. Protestants, on the other hand, reject the institutionalised faith and thus no longer have a church institution, so it seems understandable that another institution could be used for it: academia, or the university, with the promise of salvation through education.

The 'problem', if you want to call it a problem, is not the national (or even religiously biased) connotation or configuration of knowledge (production), of thought patterns or literacies but the ignorance and levelling out of them. These represent an actual danger for (educational) research by propagating a so-called objectivity and neutrality of the researchers and (in) research, while at the same time forfeiting the chance to do academic work in a historically accurate, contextually appropriate and thus meaningful way. This ignorance, in turn, shows exactly the reason why nationalism in education is such a delicate issue as mentioned in the beginning. Nationalism has the appearance of danger and radicalism, the appearance of something that affects 'only others', even though it has been inscribed (to put it in Protestant terms) in our souls, as it has been since the time of nation-state-building. Both religious and nationalist motives have been naturalised, but perhaps it is the apparent absence of religion in the national that is so irritating that the phenomenon as a whole is negated in educational research. And perhaps this is why it is all the more important to recognise these 'national lenses' in order to become more productive in fields of research, education and nationalism.

\section{Disclosure statement}

No potential conflict of interest was reported by the author. 


\section{References}

Acosta, F. (2020). 'Doing nation' at the origins of secondary education in Argentina: the case of the colegio nacional (national school). Croatian Journal of Education, 21(6), 115-132, (this (special) issue).

Anderson, B. (1991). Imagined Communities. Reflections on the Origin and Spread of Nationalism. Verso.

Beck, U. (2002). The Cosmopolitan Socitey \& Its Enemies. Theory, Culture \& Society, 19(1-2), 17-44.

Beck, U. (2005). Power in the Global Age: A New Political Economy. Polity Press. https://doi. org/10.1177/026327640201900101

Beller, S. (2017). A Concise History of Austria (13th ed.). Cambridge University Press.

Boyer, J. W. (1989). Some Reflections on the Problem of Austria, Germany, and Mitteleuropa. Central European History, 22(3/4), 301-316. https://doi.org/10.1017/S0008938900020501

Brezinka, W. (2000). Pädagogik in Österreich. Die Geschichte des Faches an den Universitäten vom 18. bis zum Ende des 20. Jahrhunderts. Band 1, Wien. Verlag der Österreichischen Akademie der Wissenschaften.

Buchardt, M. (2020). Between 'dannelse' and 'real life'. National Cultural Christianity in a Nordic Cold War education reform process. International Journal for the Historiography of Education, 10(2), 188-202.

Buchardt, M., Markkola, P., \& Valtonen, H. (Eds.) (2012). Education, state and citizenship. Bookwell Oy.

Calhoun, C. (1977). Nationalism. University of Minnesota Press.

Chernilo, D. (2011). The critique of methodological nationalism. Thesis Eleven, 106(1), 98117. https://doi.org/10.1177/0725513611415789

de Cillia, R. (1995). Deutsche Sprache und österreichische Identität. Medien Impulse, 14, 4-13.

Condorcet, J.-A.-N. de Caritat, Marquis de (1792). Rapport et projet de décret sur l'organisation générale de l'instruction publique. Présentés à l'Assemblée nationale, au nom du comité d'instruction publique. Imprimerie nationale.

Cowen, R. (2009). The transfer, translation and transformation of educational processes: and their shape-shifting? Comparative Education, 45(3), 315-327. https://doi. org/10.1080/03050060903184916

Cummings, W. K. (1999). The Institutions of Education: Compare, Compare, Compare! Comparative Education Review, 43(4), 413-437. https://doi.org/10.1086/447578

Fichte, J. G. (1808). Reden an die deutsche Nation. Realschulbuchhandlung.

Fleck, L. (1999). Entstehung und Entwicklung einer wissenschaftlichen Tatsache. Einführung in die Lehre vom Denkstil und Denkkollektiv (4th ed). Suhrkamp.

Foucault, M. (1973). Archäologie des Wissens (U. Köppen, Trans.). Suhrkamp. (Original work published 1969)

Foucault, M. (1976). Sexualität und Wahrheit: 1. Band: Der Wille zum Wissen (U. Raulff \& W. Seitter, Trans.). Suhrkamp. 
Gotling, N. (2020). National Textbook Narratives and Historiography: Presenting a Same That is Never the Same. Croatian Journal of Education, 21(6) (this (special) issue).

Hacking, I. (2002). Historical Ontology. Harvard University Press.

Haderlap, M. (November 12, 2018). Festrede zum Staatsakt anlüsslich 100 Jahre Gründung der Republik [Video file].https://tvthek.orf.at/profile/Archiv/7648449/Staatsakt-anlaesslich100-Jahre-Gruendung-der-Republik/13995280/Festrede-von-Schriftstellerin-MajaHaderlap/14395702

Harp, S. (1998). Learning to be loyal. Primary Schooling as Nation Building in Alsace and Lorraine, 1850-1940. Northern Illinois University Press.

Heydemann, K. (2000). Klassische (Deutsche) Literatur aus Österreich. Sbornik praci filozoficke fakulty Brnenske Univerzity. Studia minora facultatis philosophicae Universitatis Brunensis $R, 5(1), 121-145$.

Hofmann, M. (2020). Swiss Alpine Milk, Education and the Fabrication of the Ideal Swiss Citizen. Croatian Journal of Education, 21(6) (this (special) issue).

Horlacher, R. (2020). Doing nation by civic education. The case of Switzerland. Croatian Journal of Education, 21(6) (this (special) issue).

Humboldt, W. von (1920a). Ueber die mit dem Königsbergischen Schulwesen vorzunehmenden Reformen. In A. Leitzmann (Ed.), Wilhelm von Humboldts Werke (pp. 259-276). Behr. (Original work published 1809)

Humboldt, W. von (1920b). Unmaßgebliche Gedanken über den Plan zur Einrichtung des Litthauischen Stadtschulwesens. In A. Leitzmann (Ed.), Wilhelm von Humboldts Werke (pp. 276-283). Behr. (Original work published 1809)

Koch, H.-A. (2008). Die Universität. Geschichte einer europäischen Institution. Wissenschaftliche Buchgesellschaft.

Maricic, V. (2020). 'National Identity' School-Books: Teaching Scottishness in the Wake of the Union of Parliaments. Croatian Journal of Education, 21(6) (this (special) issue).

Milde, V. E. (1818). Lehrbuch der allgemeinen Erziehungskunde im Auszuge. Erster Teil. Strauß. (Original work published 1814)

Niemeyer, A. H. (1818). Grundsätze der Erziehung und des Unterrichts, Teil 1 (7th edition). Author's edition. (Original work published 1799)

Nordenbo, S. E. (1997). Danish Didactics: an outline of history and research. Scandinavian Journal of Education Research, 41(3), 209-224. https://doi.org/10.1080/0031383970410304

Özkırıml, U. (2010). Theories of Nationalism. A Critical Introduction. Palgrave Macmillan.

Pocock, J. G. A. (1987). The Concept of Language and the Métier d'historien: Some Considerations on Practice. In A. Pagden (Ed.), The Languages of Political Theory in Early-Modern Europe (pp. 19-38). Cambridge University Press. https://doi.org/10.1017/ CBO9780511521447.002

Radeiski, B. (2017). Denkstil, Sprache und Diskurse. Überlegungen zur Wiederaneignung Ludwik Flecks für die Diskurswissenschaft nach Foucault. Frank \& Timme.

Renan, E. (1992). What is a nation? [Paper presentation]. In Qu'est-ce qu'une nation?. Conference 
faite en Sorbonne (France). Presses-Pocket.

Rodrik, D. (2019). Foreword. In Y. Tamir (Ed.), Why Nationalism (pp. ix-xii). Princeton University Press. https://doi.org/10.1515/9780691193359-001

Rush, B. (1947). On Education. In D. Runes (Ed.), The Selected Writings of Benjamin Rush (pp. 85-130). Philosophical Library.

de Saussure, F. (2016). Grundfragen der allgemeinen Sprachwissenschaft. Eine Auswahl (U. Bossier, Trans.). Reclam. (Original work published 1916)

Shalev Marom, M. (2020). Waking up Schrödinger's cat: Black-Jews, Ethopian-Israelis, and the im-possibility of a Jewish State. Croatian Journal of Education, 21(6) (this (special) issue).

Surman, J. (2019). Universities in Imperial Austria 1848-1918. A Social History of a Multilingual Space. Purdue University Press.

Tröhler, D. (2011). Languages of Education. Protestant Legacies, National Identities, and Global Aspirations. Routledge. https://doi.org/10.4324/9780203828427

Tröhler, D. (2017). Tracking the Educationalization of the World: Prospects for an Emancipated History of Education. Pedagogika, 67(3), 211-226. https://doi.org/10.14712/23362189.2017.1019

Tröhler, D. (2018). Internationale Provokationen an nationale Denkstile in der Erziehungswissenschaft: Perspektiven Allgemeiner Pädagogik. International Journal for the Historiography of Education, 8(2), 173-189.

Tröhler, D. (2020). National literacies, or modern education and the art of fabricating national minds. Journal of Curriculum Studies (online), 1-17. https://doi.org/10.1080/00 $\underline{220272.2020 .1786727}$

Tröhler, D., Popkewitz, T. S., \& Labaree, David, F. (Eds.) (2011). Schooling and the Making of Citizens in the Long Nineteenth Century. Routledge. https://doi.org/10.4324/9780203818053

Tröhler, D., \& Fox, S. (2019). Der 'linguistic turn' und die historische Bildungsforschung. Enzyklopädie Erziehungswissenschaft Online (EEO). Beltz Juventa.

Tröhler, D., \& Horlacher, R. (2019). Histories of Ideas and Ideas in Context. In T. Fitzgerald (Ed.), Handbook of Historical Studies in Education: Debates, Tensions, and Directions. Springer. https://doi.org/10.1007/978-981-10-0942-6 2-1

Tröhler, D., \& Maricic, V. (in review). Education and the nation: Educational knowledge in the dominant theories of nationalism. Review of Educational Research.

Universität Wien (Ed.) (1831-2004). Vorlesungsverzeichnis / Universität Wien. Berger.

Vermeiren, J. (2011). Germany, Austria, and the Idea of the German Nation 1871-1914. History Compass, 9(3), 200-214. https://doi.org/10.1111/j.1478-0542.2010.00758.x

Webster, N. (1790). On the Education of Youth in America. Thomas and Andrews.

Weiss, F. (2000). Austria from European State to Nation State in Europe. In M. Andenas (Ed.), Judicial Review in International Perspective, Liber Amicorum in Honour of Lord Slynn of Hadley (pp. 89-99). Kluwer Academic Publishers.

Whatmore, R. (2017). What is intellectual History? Polity Press.

Wimmer, A., \& Glick Schiller, N. (2002). Methodological nationalism and beyond: nation- 
state building, migration and the social sciences. Global Networks, 2(4), 301-334. https:// doi.org/10.1111/1471-0374.00043

Wodak, R., de Cillia, R., Reisigl, M., \& Liebhart, K. (2009). The Discursive Construction of National Identity. Edinburgh University Press.

\author{
Stephanie Fox \\ Department of Education \\ University of Vienna \\ Sensengasse 3a, 1090 Vienna, Austria \\ stephanie.fox@univie.ac.at
}




\section{Zaplet nacije i epistemologije: pogledi u stražnje dvorište akademskoga dostojanstva}

\section{Sažetak}

U ovom radu govori se o pojavi 'nacionalnih epistemologija' kao posebnih načina razmišljanja o svijetu, oboje omogućenim i ograničenim nacionalnim/ nacionalističkim ideologijama poput kulturološke teze o izrazitoj sličnosti $i$ zajedništvu. S obzirom na metodologiju, u ovom radu općenito se opisuje način identifikacije 'nacionalne epistemologije' i posebno način objašnjavanja njihovoga razvoja kao nacionalno idiosinkratičnih načina konceptualizacije i provođenja istraživanja, uzimajući kao primjer područje akademskoga obrazovanja. Postojanje takvoga izrazito nacionalnoga stila istraživačke misli može se utvrditi, barem na Zapadu: u Sjedinjenim Američkim Državama, Francuskoj, Engleskoj i Njemačkoj. Stoga, imperijalističke težnje tih nacionalno obojanih $i$ konfiguriranih fenomena dolaze u prednji plan, ukazujući na njihova nastojanja širenja od epistemološki jačih nacija (država) na slabije, uz pomoć 'putujućih ideja'. Počevši od stila misli njemačkog idealizma, utvrdena su dva glavna razloga ili svrhe tih putovanja: „pozivom” i „okupacijom”, kao što je predstavljeno na slučaju Austrije.

Ključne riječi: Austrija; nacionalne epistemologije; nacionalizam; putujuće ideje; obrazovno istraživanje. 